\title{
Causes and Consequences of Reforming in Electricity Production and Consumption Pattern on Promoting Sustainable Development in Iran: An Economic Analysis
}

\section{Ali Mohammadipour}

Economics Consultant, Department of Energy, Iranian Association for Energy Economies, Tehran, Iran $\dagger$ Corresponding author: Ali Mohammadipour; dr.ali.mohammadipour@gmail.com

\author{
Nat. Env. \& Poll. Tech. \\ Website: www.neptjournal.com \\ Received: 02-04-2020 \\ Revised: $19-06-2020$ \\ Accepted: 25-06-2020 \\ Key Words: \\ Power Industry \\ $\mathrm{CO}_{2}$ emissions \\ Sustainability \\ Sustainable development
}

\begin{abstract}
In line with the 2015 Paris Agreement, the present study examines the efficiency of Iran's electricity industry compared to world standards. In 2018, Iran is ranked second in the world in terms of direct subsidies to the electricity industry, while subsidies for fossil fuels as the main feedstock for power plants are also higher. The results of the study indicate that despite the privatization of the electric industry since 2005, centralized economic management and the provision of extensive direct and indirect subsidies have led to the expansion of inefficiencies in the production and consumption of electricity. Lack of cost-based pricing is a major factor in the production of inefficient units and the determination of electricity prices at very low levels (as a result of subsidies) is the main reason for the inefficient use of electricity in Iran. The undeniable role of fossil fuels in energy production has stabilized Iran's second-largest power plant sector in $\mathrm{CO}_{2}$ emissions in the Middle East, and as a consequence of no noticeable changes in the energy production process, the carbon intensity index and carbon intensity for electricity consumption, have fluctuated slightly. However, the energy intensity and energy intensity for electricity consumption, unlike the developed countries, have shown an upward trend, indicating a decline in energy and electrical energy efficiency in the Iranian economy. The index of fundamental reforms in electricity production, exactly the reverse of the successes in Iceland, Switzerland, Norway, Sweden and Luxembourg, is less than $8 \%$, which is against sustainable development goals. It is crucial to take advantage of countries' successful experiences in electricity price reform and to address the four key components proposed.
\end{abstract}

\section{INTRODUCTION}

Energy, and especially electricity, is one of the most important inputs of production which, as a fundamental input, plays an important role in the economic growth and development of any country. The lack of proper energy utilization and even weak access to electricity is the main cause of economic and social backwardness in different societies. As a result of increasing efficiency in energy production and consumption, especially electricity, living standards and welfare of communities will increase and economic growth and development will be achieved. Economic growth, by greater use of all production factors and electricity, will increase the production of final goods. Both the increase in energy consumption and the production process of intermediate and final goods require environmental degradation and environmental pollution. According to Environment Kuznets Curve Hypothesis, there is an inverse U relationship between economic growth and environmental pollution, and economic growth will be valuable if it continues to reduce environmental pollution (Sajadifar et al. 2016). With the industrial development of societies, the role of the electricity industry in the economic development programs of countries has increased. The dramatic growth in demand for this strategic input has led researchers to look for ways to increase efficiency in electricity generation and to focus more on factors affecting production costs and electricity prices (Pourebadollahan et al. 2019) Price changes in energy carriers and their impact on electricity prices are important concerns for the electricity market players and observers. In Iran, electricity prices are set according to the government's tariff, and fuel prices for power plants are also subsidized. Therefore, the supply and demand side of the electricity market is kept away from the effects of fuel price fluctuations and all the risks of price changes are transferred to the government (Moshiri et al. 2018). According to International Energy Agency (2019b) reports in 2018, Iran has the largest amount of subsidies to the energy sector in the world, and in terms of electricity subsidies (after China), it is the second largest in the world. In addition to widespread subsidies, the strong dependence of power plants on fossil fuels has intensified $\mathrm{CO}_{2}$ emissions. 
The present study, considering environmental concerns, examines the production process and electricity consumption pattern and seeks to provide solutions for implementing sustainable development in the Iranian electric industries.

\section{ELECTRICAL INDUSTRIES IN IRAN}

Iran, as the first country in the Middle East, began restructuring studies in the electricity industry, and by making the power plants profitable, the private sector has a greater desire to enter the electricity market and speed up the privatization process. In 2014, the fourth Iranian stock exchange, Electricity-Based Energy Stock Exchange, was launched (Kianvand \& Farzinvash 2015).

Private sector activity remained modest at less than $14 \%$ by 2012, and in 2013 there was a significant jump in the nominal and practical capacity of the private sector. According to the plan, by 2022, 15747 MW (MegaWatts) of power will be built by the non-governmental sector, of which 12,468 MW will be added to thermal power plants and the rest to renewable (mostly solar) power plants. Currently, 44.9 percent of the total nominal capacity of the country's power plants belongs to the Ministry of Energy, 46.3 percent to the private sector, 7.5 percent to large industries, and 1.3 percent to the Iranian Atomic Energy Organization. According to Fig. 1, in 2017 the ratio of practical to nominal capacity of the country's power plants is $86.6 \%$ and the same ratio for the private sector is $83.1 \%$.
Iran has electrical connections with countries with a common land border. The regional electricity cooperation plan could cause Iran to transfer electricity to nonneighbouring countries and ultimately a precondition for connecting Iran's electricity to the European electricity grid. One of the major goals of the Energy Ministry is to improve the country's position in the role of Energy Bridge and become the electricity hub in the region. Very small amounts of electricity trade in Iran can be seen in Fig. 2 and exports have increased more than imports since 2007.

\section{RESEARCH BACKGROUND}

According to Bose (2010) and Stern (2014), environmental concerns and the increasing depletion of fossil fuel resources have led to the efficient use of heat and power cogeneration systems. According to the U.S. Environmental Protection Agency (2014) report, the emissions of environmental pollutants in the most widely used technologies in heat and power cogeneration systems for solar thermal renewables, non-renewable fuel cells, internal combustion engines and microturbines are $0,0.02,0.79$ and $0.15 \mathrm{Kg}_{\text {of }} \mathrm{CO}_{2}$ produced per kWh, respectively. According to Foley et al. (2014), as the price of Natural Gas increases, the wholesale price of electricity will also increase. Wang \& Wei's (2016) study supports Porter's hypothesis in China and, according to this hypothesis, stricter environmental regulations increase

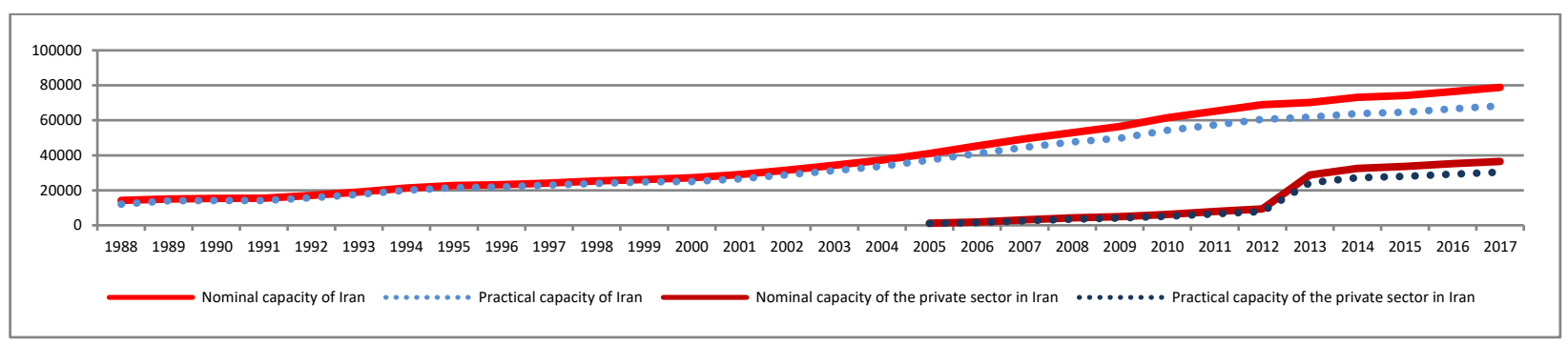

Reference: Ministry of Power. 2020. An Overview of Energy Statistics in Iran (30 year energy statistics).

Fig. 1: Nominal and practical capacity of the power industry in Iran (with private sector capacity) - Data unit: Megawatt

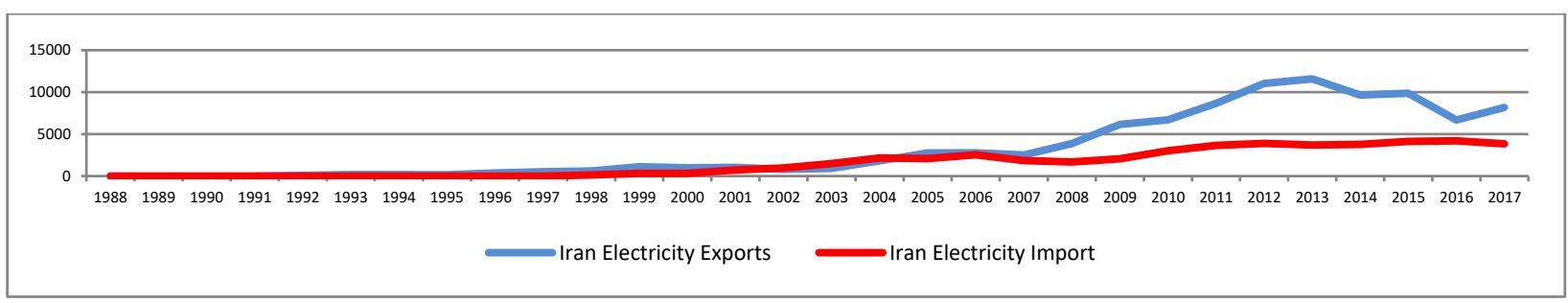

Reference: Ministry of Power. 2020. An Overview of Energy Statistics in Iran (30 year energy statistics).

Fig. 2: Exports and imports of electricity in Iran - Data unit: Million kWh. 
efficiency and improve innovation and enhance commercial competitiveness. According to Shih et al. (2016) in Taiwan, with the decline of land capacity and population growth, the environment is becoming increasingly important and more action must be taken to replace renewable energy.

According to Razmi et al. (2010), due to the many shortcomings in creating a competitive environment in the Iranian electricity market, the reduction of concentration and the move to the competitive market should be considered by the planners. Razini et al. (2011) outline three scenarios for the future of Iran's electricity industry, stating that by 2030 , fossil-fuel resources can be reduced to $67 \%$ by renewable energy planning. According to Sajadifar et al. (2016), operational plans should be implemented in order to conserve available resources and reduce environmental degradation due to adverse efficiency changes for Iran and neighbouring countries during 2007-2012. According to Majdzadeh Tabatabaei et al. (2016), in Iran only electricity generation from renewable wind energy is activated and there is still no growth in solar and biogas production. According to Kachoi \& Amidpour (2016), the intensity of $\mathrm{CO}_{2}$ emission in the scenario of increasing the efficiency of the power generation sector is lower than the continuation scenario of the current trend and can be drastically reduced in the scenarios of renewables. According to Kiani et al. (2017), new energies, despite being unfinished and having no negative external effects, impose significantly higher costs to the government than non-renewable resources. According to Gholipour Khatir et al. (2018), the positive effect of subsidy removal on the technical efficiency of power plants in Iran cannot be verified; however, in private power plants, increasing the input-output ratio increases efficiency.

\section{ANALYZING SUSTAINABLE DEVELOPMENT DIMENSIONS IN IRANIAN ELECTRIC INDUSTRIES}

The concept of sustainability emerged in response to the increased understanding that contemporary development practices were leading to a crisis in a social and environmental sense. The term "sustainable development" thus became the buzzword for alternative development strategies that could be "envisioned as continuing far into the future" (Wheeler Stephen 2013). There are several definitions of sustainability, but some are more inclusive than others. The official definition adopted by the United Nations (UN) came from the Brundtland report which defined sustainable as "development that meets the needs of the present generation without compromising the ability of future generations to meet their own needs" (Tladi 2007). Environmental, economic and social aspects are three important dimensions of sustainable development (UN 2011). These dimensions are discussed below for sustainable development in the electricity industry in Iran.

\section{Production Process Analysis in the Electric Industries in Iran}

The increasing emissions of greenhouse gases into the atmosphere as a result of the overuse of fossil fuels have become one of the most undesirable effects of economic development and have recently become a global issue. In Iran, the power plant sector, with $30.2 \%$ share of the total $\mathrm{CO}_{2}$ emissions, is the largest emitter of greenhouse gases (Kachoi \& Amidpour 2016). According to IEA (2019a) reports, Iran was ranked $24^{\text {th }}$ in the world in terms of $\mathrm{CO}_{2}$ emissions in $1980,14^{\text {th }}$ in $2000,9^{\text {th }}$ in 2010 and $8^{\text {th }}$ in 2016 and 2017 , with the increasing volume of pollution, compared to Canada.

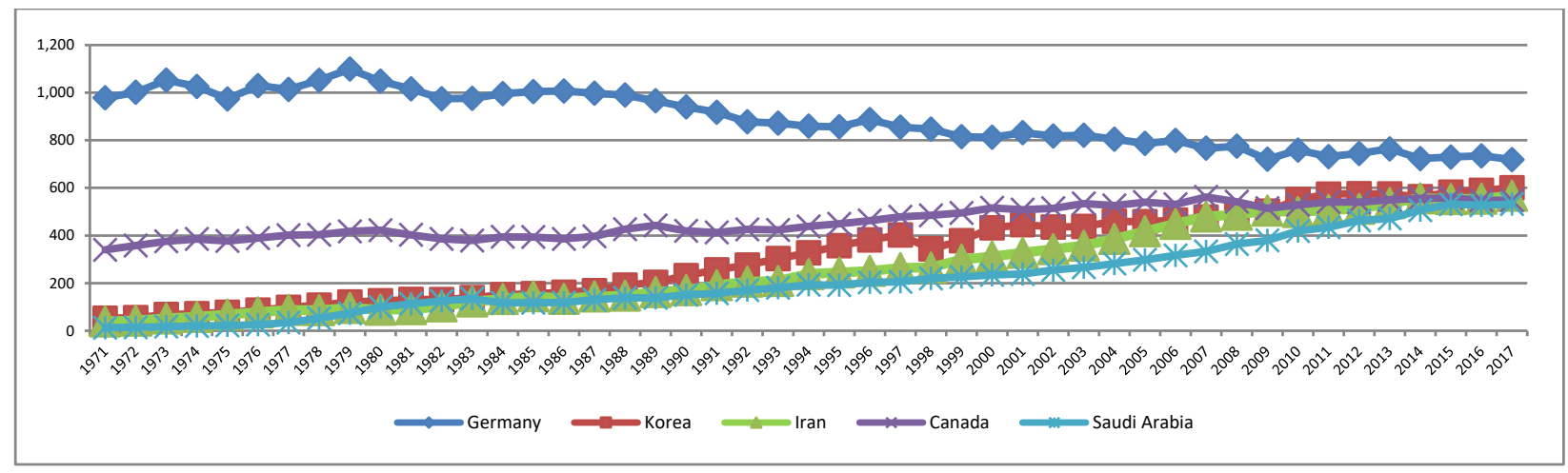

Reference: IEA. 2019a. $\mathrm{CO}_{2}$ Emissions from Fuel Combustion Highlights.

Fig. 3: $\mathrm{CO}_{2}$ emissions in selected countries $\left(6^{\text {th }}\right.$ to $10^{\text {th }}$ world $\mathrm{CO}_{2}$ emissions rates $)$ - Data unit: Million tons of $\mathrm{CO}_{2}$. 


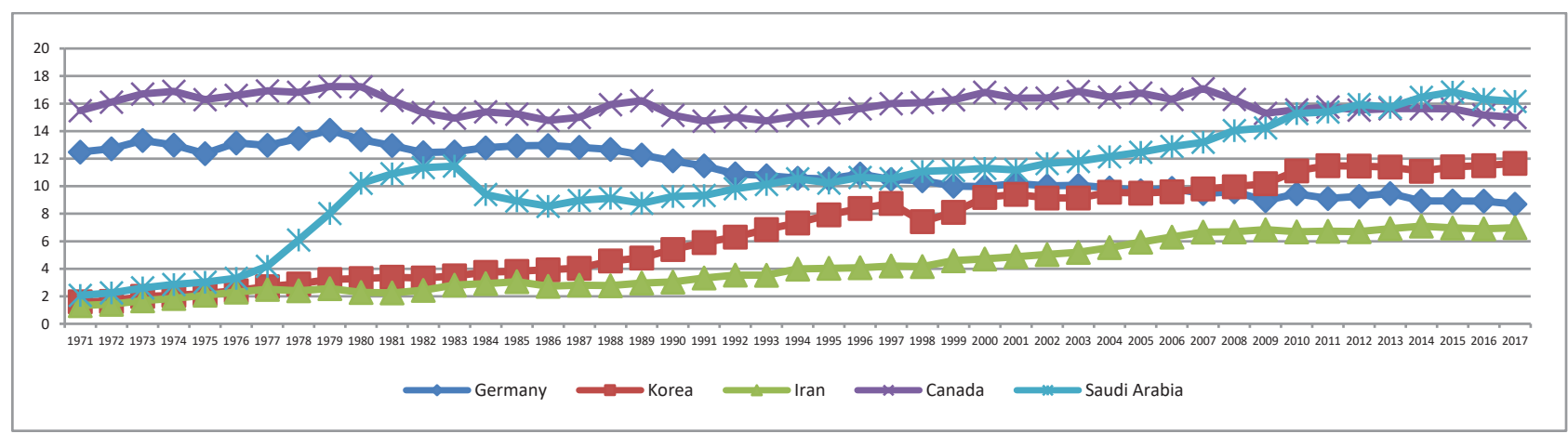

Reference: IEA. 2019a. $\mathrm{CO}_{2}$ Emissions from Fuel Combustion Highlights.

Fig. 4: $\mathrm{CO}_{2}$ emissions/population index in selected countries $\left(6^{\text {th }}\right.$ to $10^{\text {th }}$ world $\mathrm{CO}_{2}$ emissions rates $)$.

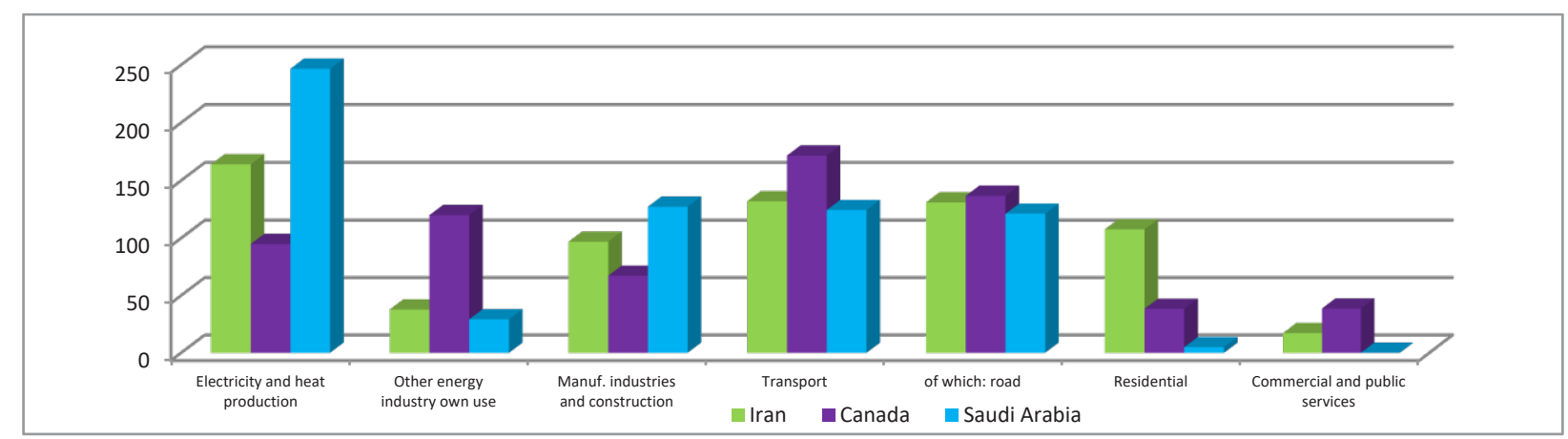

Reference: IEA. 2019a. $\mathrm{CO}_{2}$ Emissions from Fuel Combustion Highlights.

Fig. 5: $\mathrm{CO}_{2}$ emissions in different parts of Iran, Canada and Saudi Arabia in 2017 - Data unit: Million tons of $\mathrm{CO}_{2}$.

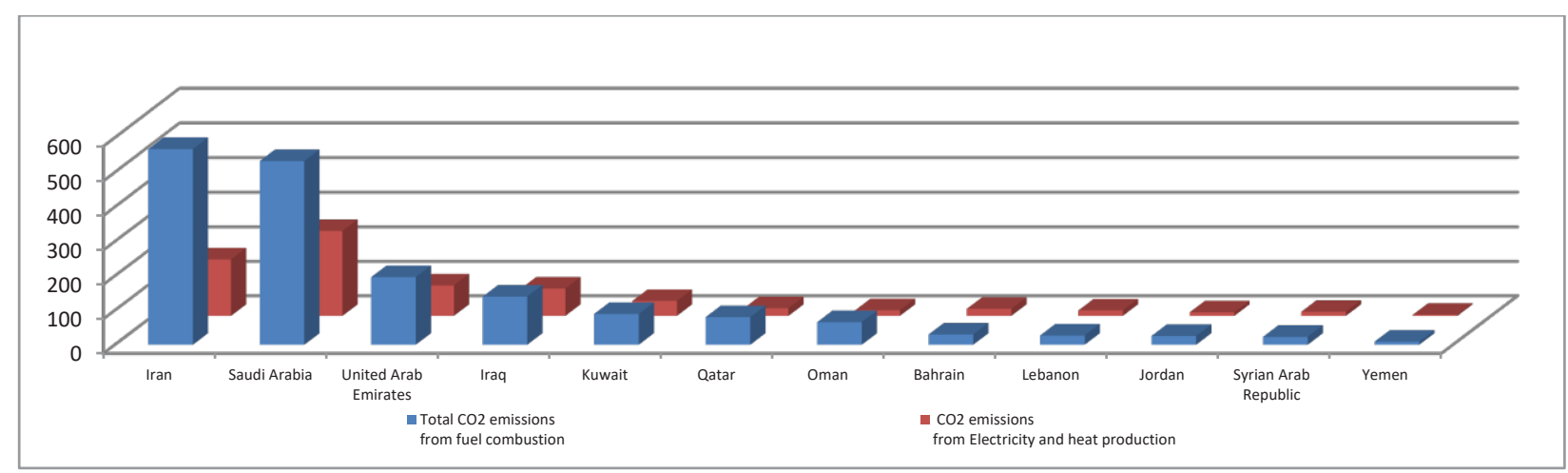

Reference: IEA. 2019a. $\mathrm{CO}_{2}$ Emissions from Fuel Combustion Highlights.

Fig. 6: Comparison of $\mathrm{CO}_{2}$ emissions in the Middle East (with emphasis on the electricity sector) in 2017 - Data unit: Million tons of $\mathrm{CO}_{2}$.

Germany ranks second in the world in terms of $\mathrm{CO}_{2}$ emissions after the USA in 1971 but has managed to reach $6^{\text {th }}$ in the world in the last 50 years using sustainable development policies. According to Fig. 3, a completely reverse trend is taking place in Iran and Saudi Arabia, and with the intensification of $\mathrm{CO}_{2}$ emissions, Iran's rank in the world has continued to rise.

Iran is better off in terms of $\mathrm{CO}_{2}$ emissions/population index than the countries mentioned, but worrying is the upward trend in Fig. 4. Of course, the uptrend of this index is 
Table 1: The world's first 14 countries in terms of $\mathrm{CO}_{2}$ emissions in the power plant sector in 2017 - Data unit: Million tons of $\mathrm{CO}_{2}$.

\begin{tabular}{|c|c|c|c|c|}
\hline $\begin{array}{l}\text { S. } \\
\text { No. }\end{array}$ & Country & $\begin{array}{l}\text { Total } \mathrm{CO}_{2} \text { emissions } \\
\text { from fuel combustion }\end{array}$ & $\begin{array}{l}\mathrm{CO}_{2} \text { emissions } \\
\text { from Electricity and heat production }\end{array}$ & $\begin{array}{l}\text { Share of Electricity and heat produc- } \\
\text { tion from } \mathrm{CO}_{2} \text { emissions }\end{array}$ \\
\hline 1 & People's Rep. of China & 9257.9 & 4591.3 & 49.59 \\
\hline 2 & United States & 4761.3 & 1822.8 & 38.28 \\
\hline 3 & India & 2161.6 & 1100.4 & 50.91 \\
\hline 4 & Russian Federation & 1536.9 & 773.5 & 50.33 \\
\hline 5 & Japan & 1132.4 & 554.9 & 49.00 \\
\hline 6 & Korea & 600.0 & 322.1 & 53.68 \\
\hline 7 & Germany & 718.8 & 303.9 & 42.28 \\
\hline 8 & Saudi Arabia & 532.2 & 246.6 & 46.33 \\
\hline 9 & South Africa & 421.7 & 225.5 & 53.47 \\
\hline 10 & Indonesia & 496.4 & 195.9 & 39.46 \\
\hline 11 & Australia & 384.6 & 191.5 & 49.79 \\
\hline 12 & Chinese Taipei & 268.9 & 165.3 & 61.48 \\
\hline 13 & Iran & 567.1 & 163.9 & 28.90 \\
\hline 14 & Mexico & 446.0 & 153.7 & 34.47 \\
\hline
\end{tabular}

Reference: IEA. 2019a. $\mathrm{CO}_{2}$ Emissions from Fuel Combustion Highlights.

much more dangerous in Saudi Arabia, however, Germany, with its principled management, has been able to downtrend this index, too.

According to Fig. 5, Iran is better off than Saudi Arabia in terms of $\mathrm{CO}_{2}$ emissions from electricity and heat production, but less favourable than Canada. Also, the electrical industries and transportation are in the first and second tier of $\mathrm{CO}_{2}$ emissions in Iran. Therefore, considering the first category of electrical industries in $\mathrm{CO}_{2}$ emission, this issue should be addressed which is the main topic of the present article.

According to Fig. 6, Iran emits the highest amount of $\mathrm{CO}_{2}$ in the Middle East and has the highest $\mathrm{CO}_{2}$ emissions from electricity and heat production in the region after Saudi Arabia.
According to Table 1, Iran is ranked $13^{\text {th }}$ in the world despite lower relative GDP, with 164 million tons of $\mathrm{CO}_{2}$ released in 2017. The electricity market is vertically linked to other commodities such as fuel (Natural Gas, Diesel Fuel, etc.) or $\mathrm{CO}_{2}$ emission permits. Electricity on a large scale cannot be stored, so a balance between production and consumption on a continuous and moment-by-moment basis must be carefully ensured (Moshiri et al. 2018).

The government has tried to replace Natural Gas with other fossil fuels due to its ease of use, reduced maintenance costs and reduced environmental impact (relative to other fossil fuels). Therefore, in Fig. 7, Natural Gas consumption in power plants has changed dramatically in the last two

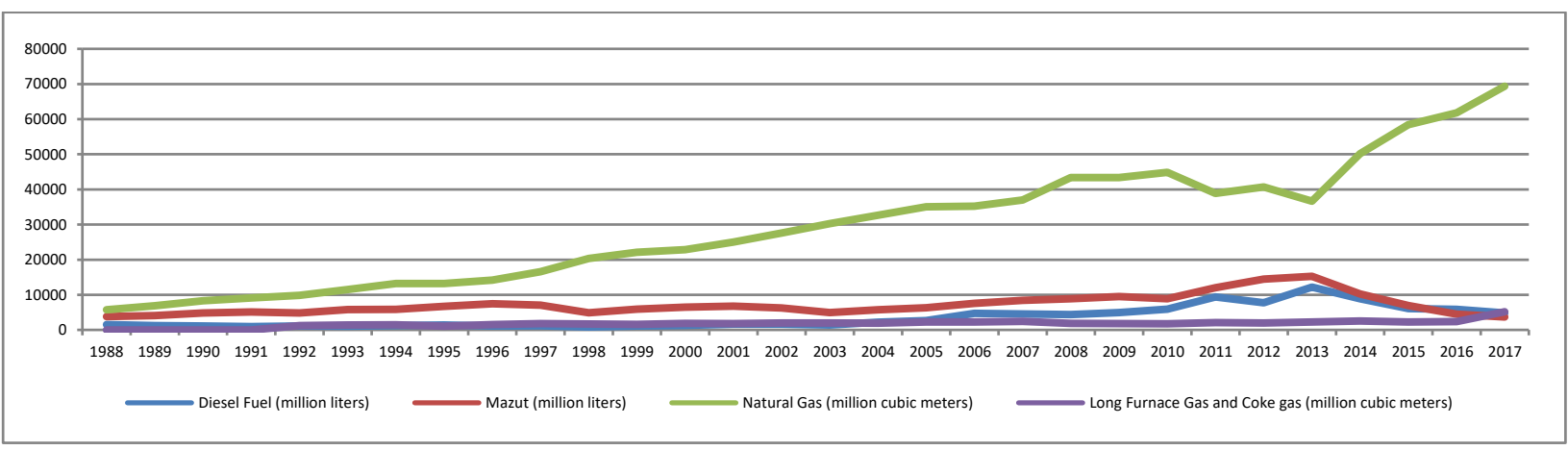

Reference: Ministry of Power. 2020. An Overview of Energy Statistics in Iran (30 year energy statistics).

Fig. 7: Fuel consumption trends in all Iranian power plants, by type of fuel. 


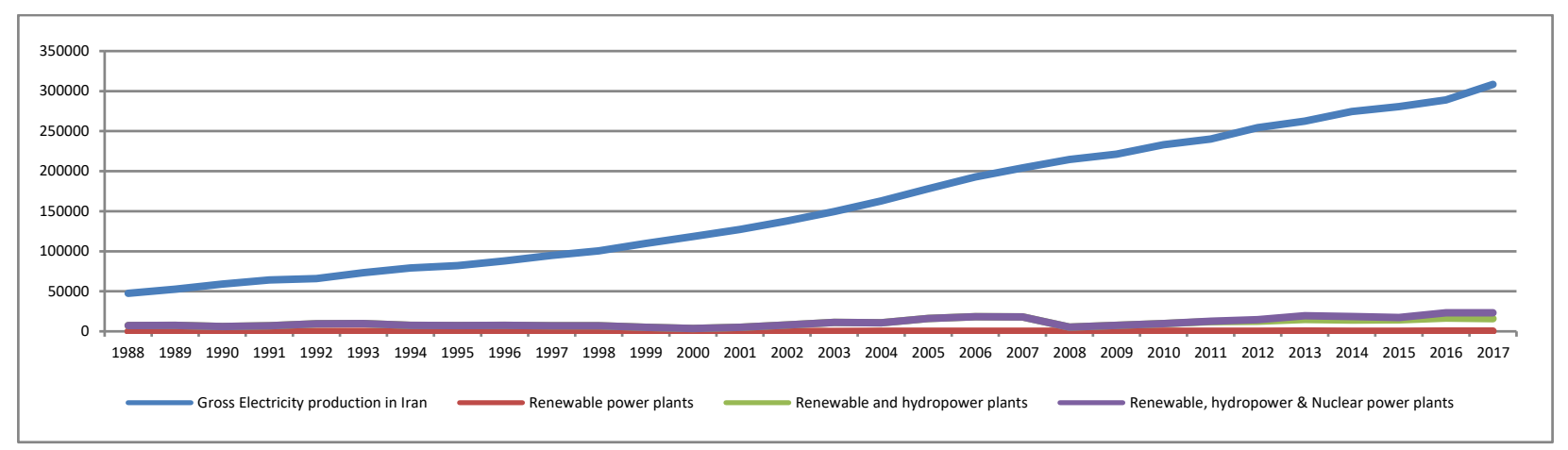

Reference: Ministry of Power. 2020. An Overview of Energy Statistics in Iran (30 year energy statistics).

Fig. 8: Trend of Gross Production of Electricity in Iran, By Specifying the Role of Non-Fossil Sectors - Data unit: Million kWh.

decades, reaching 69.4 billion cubic meters in 2017.

But first, in conditions of shortage of Natural Gas (in the cold months of the year), power plants will inevitably use alternative fuels, namely Diesel Fuel for gas and combined cycle power plants, and Mazut for steam power plants. Therefore, disconnecting the gas fuel, limiting the transportation and storage of liquid fuel, generates restrictions on the operation of the electricity grid. The use of fossil fuels instead of Natural Gas also contributes to the spread of malodour and severe environmental pollution.

Second, according to Fig. 6, even the extensive consumption of Natural Gas by Iranian power plants has not been favourable and has resulted in very high $\mathrm{CO}_{2}$ emissions.

According to Fig. 8, the share of renewable energy from Gross Production of Electricity in the past three decades has never exceeded $0.15 \%$, so its role in Iran's electricity production is negligible. The share of hydropower plants in electricity production has also fallen from $15 \%$ to $5 \%$ over the same period. The main reason for the decline in the relative share of hydropower plants is the slow pace of their increase compared to the development of the power plant sector in Iran. Electricity production at hydropower plants has increased from 7 (in 1988) to 15 (in 2017) TWh, and has doubled after thirty years. However, total electricity production in the same period has more than six times increased from 48 (in 1988) to 308 (in 2017) TWh. Finally, the Gross Production of Electricity in nuclear power plants was zero till 2011 and increased to 7.5 TWh in 2017. The index of Fundamental Reforms in Electricity Production (non-use of fossil fuels in the electricity production process), including total share of renewable power, hydropower and nuclear power plants in Iran's gross electricity production in 2017 was $7.56 \%$.

According to Table 2, the index of Fundamental Reforms in Electricity Production in Iran is very poor compared to the 30 sample countries and needs to be revised regularly.
Highly successful countries in the world, such as Iceland, Switzerland, Norway, Sweden and Luxembourg, have managed more than $90 \%$ of their electricity production from non-fossil fuel sources.

\section{Real Government Support for Iran's Electric Industry}

Based on the economic theories of the public sector and in accordance with Twomey et al. (2005) and Guler \& Gross (2005), maximum social welfare and public satisfaction are formed in a situation in which the price of each commodity is equal to the final cost of its production and in the electricity industry based on the degree of market concentration and competitiveness, one can understand the nature of pricing and the degree of competition or monopoly in the market. Market competitiveness means reducing the power of market drivers to exploit fluctuations, and in this regard, especially in the electricity market, monopoly power to set disproportionate prices is a major concern of market regulators. According to Shahidepour et al. (2005), the set of intrinsic and non-intrinsic factors such as low elasticity of electricity demand, inability to economically store electricity, transmission line congestion, delayed return on investment in electricity, etc. allow this to happen. According to Tirole (2014), due to the lack of competitiveness of many markets, government intervention using a variety of methods, such as economic regulation, is necessary to bring markets closer to full competition. Despite the ongoing privatization process, the electric industry in Iran still does not have a competitive structure, and the government only protects consumers by paying massive subsidies.

According to Table 3, in 2018 China, Iran and Russia paid the highest subsidies to the electrical industry at 25, 17 and 14 real million dollars, respectively, which is 56, 24 and 38 percent of their total subsidies.

China generally ranked first in the world in subsidies to the electricity sector, only temporarily falling to third and 
Table 2: The index of Fundamental Reforms in Electricity Production in Iran compared to 30 countries in 2017 - Data unit: TWh

\begin{tabular}{|c|c|c|c|c|c|c|c|c|c|}
\hline Country & $\begin{array}{l}\text { Electric- } \\
\text { ity from } \\
\text { Fossil } \\
\text { Fuels }\end{array}$ & $\begin{array}{l}\text { Hydro- } \\
\text { power }\end{array}$ & $\begin{array}{l}\text { Nuclear } \\
\text { power }\end{array}$ & $\begin{array}{l}\text { Electricity } \\
\text { from Bio- } \\
\text { fuels and } \\
\text { Waste }\end{array}$ & $\begin{array}{l}\text { Geother- } \\
\text { mal }\end{array}$ & $\begin{array}{l}\text { Solar, } \\
\text { Wind and } \\
\text { more }\end{array}$ & $\begin{array}{l}\text { Gross } \\
\text { produc- } \\
\text { tion of } \\
\text { electricity }\end{array}$ & $\begin{array}{l}\text { Fossil Fuel } \\
\text { Share in Elec- } \\
\text { tricity Produc- } \\
\text { tion }(\%)\end{array}$ & $\begin{array}{l}\text { The index of Fun- } \\
\text { damental Reforms } \\
\text { in Electricity } \\
\text { Production (\%) }\end{array}$ \\
\hline Iceland & 0.0 & 14.1 & - & - & 5.2 & - & 19.2 & 0.18 & 99.82 \\
\hline Switzerland & 0.9 & 37.0 & 20.4 & 2.9 & - & 1.7 & 62.9 & 1.43 & 98.57 \\
\hline Norway & 2.7 & 143.0 & - & 0.4 & - & 3.1 & 149.3 & 1.81 & 98.19 \\
\hline Sweden & 2.9 & 64.6 & 63.0 & 12.0 & - & 17.7 & 160.2 & 1.81 & 98.19 \\
\hline Luxemburg & 0.2 & 1.4 & - & 0.3 & - & 0.3 & 2.2 & 9.09 & 90.91 \\
\hline France & 57.1 & 54.4 & 398.4 & 9.8 & - & 34.5 & 554.1 & 10.30 & 89.70 \\
\hline Slovakia & 4.6 & 4.8 & 15.1 & 1.5 & - & 0.7 & 26.7 & 17.23 & 82.77 \\
\hline New Zealand & 7.8 & 25.0 & - & 0.6 & 7.5 & 2.2 & 43.1 & 18.10 & 81.90 \\
\hline Finland & 13.0 & 14.8 & 22.5 & 12.0 & - & 5.1 & 67.4 & 19.29 & 80.71 \\
\hline Canada & 131.6 & 394.5 & 99.4 & 14.0 & - & 34.9 & 674.4 & 19.51 & 80.49 \\
\hline Austria & 15.8 & 42.6 & - & 5.5 & - & 7.5 & 71.3 & 22.16 & 77.84 \\
\hline Denmark & 8.2 & - & - & 6.6 & - & 15.6 & 30.4 & 26.97 & 73.03 \\
\hline Belgium & 25.6 & 1.4 & 42.2 & 6.8 & - & 10.2 & 86.2 & 29.70 & 70.30 \\
\hline Spain & 125.3 & 21.0 & 58.1 & 6.8 & - & 63.7 & 274.8 & 45.60 & 54.40 \\
\hline England & 158.7 & 8.8 & 70.3 & 36.9 & - & 61.1 & 335.9 & 47.25 & 52.75 \\
\hline Germany & 345.2 & 26.2 & 76.3 & 58.7 & 0.2 & 148.4 & 655.0 & 52.70 & 47.30 \\
\hline Czech Rep. & 47.7 & 3.0 & 28.3 & 5.1 & - & 2.9 & 87.0 & 54.83 & 45.17 \\
\hline Chile & 43.9 & 22.0 & - & 5.5 & 0.1 & 7.4 & 79.0 & 55.57 & 44.43 \\
\hline Portugal & 34.8 & 7.5 & - & 3.6 & 0.2 & 13.2 & 59.3 & 58.68 & 41.32 \\
\hline USA & 2660.1 & 325.1 & 838.9 & 78.5 & 18.1 & 336.5 & 4257.2 & 62.48 & 37.52 \\
\hline Italy & 185.7 & 37.9 & - & 21.8 & 6.2 & 43.5 & 295.1 & 62.93 & 37.07 \\
\hline South Korea & 390.8 & 7.0 & 148.4 & 8.1 & - & 11.2 & 565.5 & 69.11 & 30.89 \\
\hline Ireland & 21.7 & 0.9 & - & 0.9 & - & 7.5 & 30.9 & 70.23 & 29.77 \\
\hline Turkey & 209.2 & 58.2 & - & 2.1 & 6.1 & 21.6 & 297.3 & 70.37 & 29.63 \\
\hline Greece & 44.4 & 4.1 & - & 0.8 & - & 9.5 & 58.8 & 75.51 & 24.49 \\
\hline Japan & 838.3 & 88.3 & 32.9 & 34.2 & 2.5 & 89.0 & 1085.2 & 77.25 & 22.75 \\
\hline Netherlands & 94.1 & 0.1 & 3.4 & 6.3 & - & 12.8 & 116.6 & 80.70 & 19.30 \\
\hline Mexico & 260.2 & 30.1 & 10.9 & 1.6 & 5.9 & 10.7 & 319.5 & 81.44 & 18.56 \\
\hline Australia & 219.4 & 16.5 & - & 3.6 & - & 20.6 & 260.2 & 84.32 & 15.68 \\
\hline Poland & 145.5 & 3.0 & - & 6.7 & - & 15.1 & 170.3 & 85.44 & 14.56 \\
\hline Iran & 285.0 & 15.4 & 7.5 & 0.1 & - & 0.4 & 308.3 & 92.44 & 7.56 \\
\hline
\end{tabular}

Reference: Ministry of Power. 2020. An Overview of Energy Statistics in Iran (30 year energy statistics).

fifth in 2013-2015 and then returning to first. Iran and Russia are also ranked second and third in the world, though in the three years since China's decline from first place, Russia has taken first place. According to table 4, the six countries mentioned have always been at the top of the list of subsidies to the electrical industry in the world.

According to Fig. 9, Iran is always among the first countries in the world in terms of subsidies to the electricity industry.
According to Fig. 10, from 2010 to 2013 China and from 2013 onwards Mexico has devoted the largest share of its subsidies to the electricity industry. Despite Iran's second rank in terms of subsidies to the electricity industry, the relative share of electricity industry subsidies in Iran is far less than the six above-mentioned countries, which is illustrated in Figs. 11 and 12.

Due to the abundance of Natural Gas in Iran, and according to Fig. 11, the share of Natural Gas far exceeds the 
Table 3: Top 10 Countries Paying Most Subsidies for Electricity in 2018.

\begin{tabular}{|c|c|c|c|c|c|c|c|c|c|c|}
\hline N. & Country & 2010 & 2011 & 2012 & 2013 & 2014 & 2015 & 2016 & 2017 & 2018 \\
\hline \multicolumn{11}{|c|}{ The top 10 countries in the world are the largest subsidies for the electricity sector - Unit: Real 2018 million USD } \\
\hline 1 & China & 31,617 & 33,600 & 24,943 & 14,453 & 11,151 & 7,062 & 28,196 & 22,624 & 24,857 \\
\hline 2 & Iran & 12,978 & 12,985 & 17,917 & 15,425 & 15,006 & 12,791 & 4,963 & 14,419 & 16,587 \\
\hline 3 & Russia & 17,228 & 15,835 & 16,748 & 16,737 & 17,064 & 16,561 & 21,641 & 9,442 & 14,334 \\
\hline 4 & Mexico & 6,924 & 5,778 & 5,911 & 5,769 & 5,164 & 6,786 & 10,093 & 11,685 & 13,502 \\
\hline 5 & Saudi Arabia & 15,204 & 14,353 & 14,827 & 14,138 & 13,609 & 13,536 & 10,701 & 10,975 & 12,793 \\
\hline 6 & Egypt & 2,677 & 3,974 & 4,353 & 4,623 & 3,806 & 3,682 & 3,443 & 8,131 & 12,137 \\
\hline 7 & Indonesia & 6,418 & 7,681 & 7,574 & 8,712 & 13,516 & 8,656 & 11,549 & 5,387 & 7,330 \\
\hline 8 & Venezuela & 2,147 & 1,587 & 2,557 & 6,808 & 4,546 & 2,506 & 2,087 & 4,667 & 6,512 \\
\hline 9 & India & 2,992 & 4,053 & 3,237 & 5,471 & 3,540 & 2,750 & 2,614 & 0 & 4,351 \\
\hline 10 & South Africa & 0 & 0 & 0 & 0 & 0 & 2,684 & 6,014 & 5,324 & 4,158 \\
\hline \multicolumn{11}{|c|}{ The top 10 countries in the world are the largest subsidies for the electricity sector - Unit: Percentage } \\
\hline 1 & China & 72 & 73 & 66 & 49 & 43 & 35 & 64 & 56 & 56 \\
\hline 2 & Iran & 18 & 23 & 19 & 18 & 19 & 25 & 16 & 30 & 24 \\
\hline 3 & Russia & 54 & 48 & 51 & 51 & 51 & 48 & 65 & 44 & 38 \\
\hline 4 & Mexico & 42 & 23 & 24 & 40 & 66 & 100 & 93 & 99 & 99 \\
\hline 5 & Saudi Arabia & 26 & 21 & 20 & 20 & 20 & 24 & 27 & 25 & 29 \\
\hline 6 & Egypt & 18 & 19 & 21 & 22 & 23 & 35 & 43 & 42 & 46 \\
\hline 7 & Indonesia & 35 & 28 & 21 & 26 & 36 & 47 & 63 & 29 & 23 \\
\hline 8 & Venezuela & 16 & 12 & 14 & 24 & 17 & 24 & 28 & 30 & 32 \\
\hline 9 & India & 13 & 10 & 7 & 12 & 10 & 14 & 17 & 0 & 17 \\
\hline 10 & South Africa & - & - & - & - & - & 100 & 100 & 100 & 100 \\
\hline
\end{tabular}

Reference: IEA. 2019b. Fossil-Fuel Subsidies Report.

Table 4: Top 6 countries in the world in terms of subsidies paid to the electricity industry in the last decade.

\begin{tabular}{|c|c|c|c|c|c|c|c|c|c|}
\hline Country & 2010 & 2011 & 2012 & 2013 & 2014 & 2015 & 2016 & 2017 & 2018 \\
\hline China & 1 & 1 & 1 & 3 & 5 & 5 & 1 & 1 & 1 \\
\hline Iran & 4 & 4 & 2 & 2 & 2 & 3 & 7 & 2 & 2 \\
\hline Russia & 2 & 2 & 3 & 1 & 1 & 1 & 2 & 5 & 3 \\
\hline Mexico & 5 & 7 & 7 & 7 & 7 & 6 & 5 & 3 & 4 \\
\hline Saudi Arabia & 3 & 3 & 4 & 4 & 3 & 2 & 4 & 4 & 5 \\
\hline Indonesia & 6 & 5 & 5 & 5 & 4 & 4 & 3 & 7 & 7 \\
\hline
\end{tabular}

Reference: IEA. 2019b. Fossil-Fuel Subsidies Report.

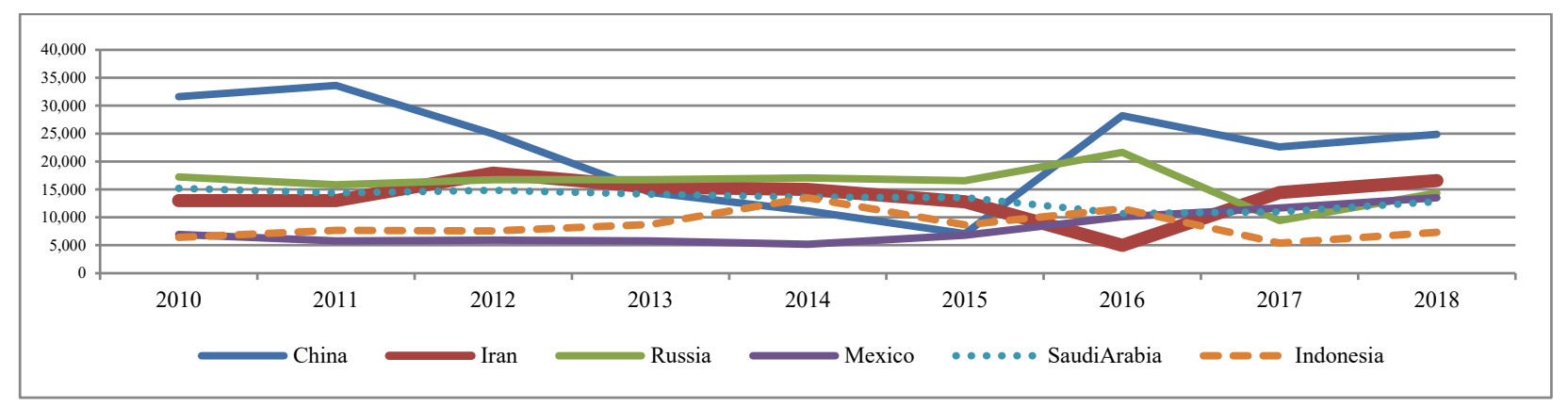

Reference: IEA. 2019b. Fossil-Fuel Subsidies Report.

Fig. 9: The trend of subsidies paid to the electric industry in the first 6 countries - Data unit: Real 2018 million USD. 
global average of subsidies paid, and the relative share of the oil and electricity sectors is lower than the global average.

According to Fig. 12, the electricity industry is the lowest in terms of subsidies compared to the gas and oil sectors. Thus, much more support for the two gas (Natural Gas) and oil (Diesel Fuel, Mazut and other fuels) sectors, that supply most of the power plant's fuel, indirectly affects the electricity industry. Obviously, the sum of direct and indirect subsidies constitutes the actual amount of subsidies to the electricity industry, and under such widespread subsidies, the supply and demand mechanisms in this industry will undoubtedly be ineffective and economic theories will lose their effectiveness. A rapid increase in energy consumption, acceleration of environmental pollution, desire to smuggle energy from Iran to neighbouring countries, decreasing industrial and economic efficiency and imposing the burden of energy subsidies on the government budget were among the most significant adverse effects on the Iran economy resulting from the pricing of energy carriers at a much lower level than the world price. Therefore, the first step in reforming the pattern of energy consumption, and especially electricity, is to gradually reduce the amount of direct and indirect subsidies to the industry. In order to realize the supply and demand mechanisms in this industry, efficiency

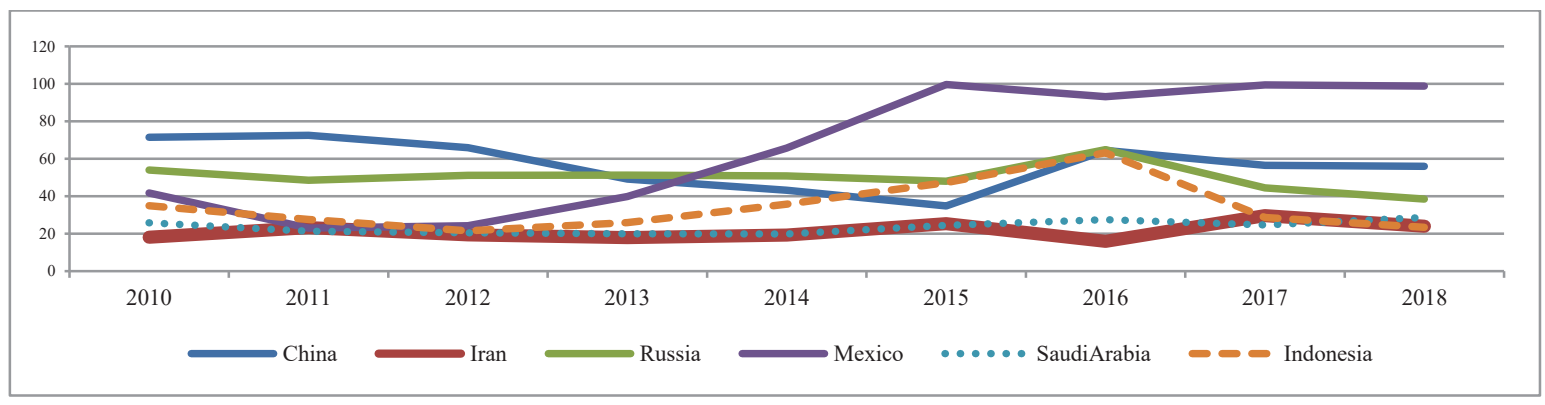

Reference: IEA. 2019b. Fossil-Fuel Subsidies Report.

Fig. 10: Share of subsidies paid to the electricity industry to total subsidies in the first 6 countries - Unit: Percentage.

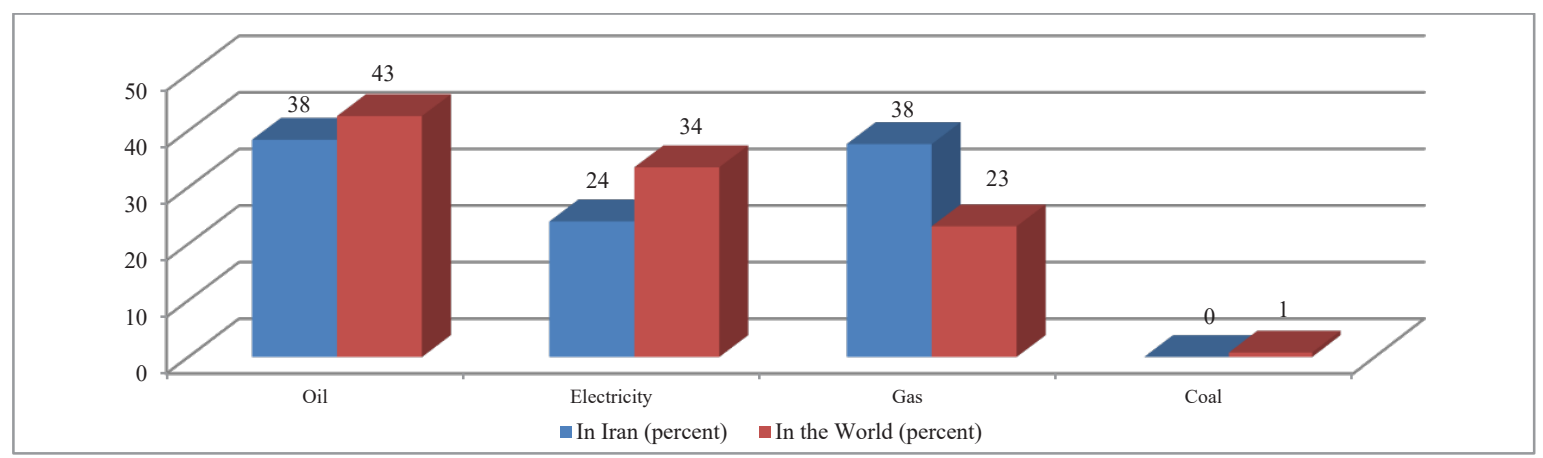

Reference: IEA. 2019b. Fossil-Fuel Subsidies Report.

Fig. 11: Relative share of subsidies paid to the four major sectors in Iran and the world in 2018 - Unit: Percentage.

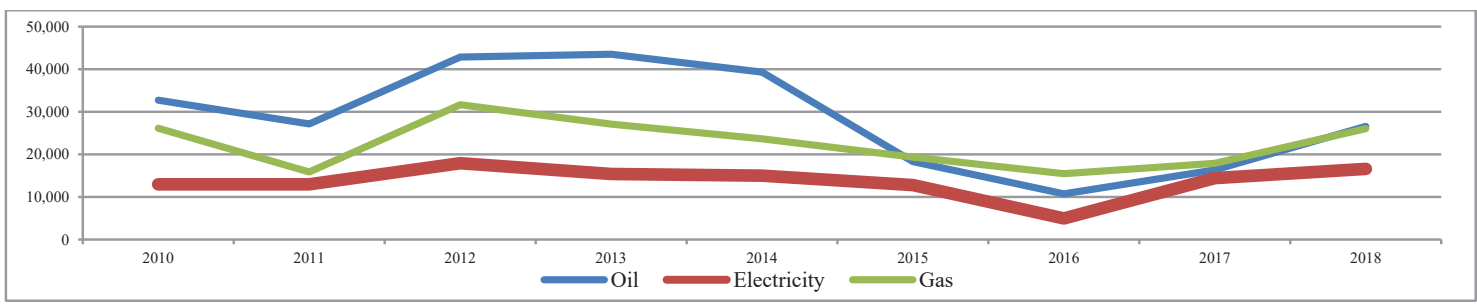

Reference: IEA. 2019b. Fossil-Fuel Subsidies Report.

Fig. 12: Amounts of subsidies paid to various sectors of Iran in 2018 - Data unit: Real 2018 million USD. 
and maximum prosperity in the electricity industry will be established according to economic theories.

\section{Social Indicators of Energy Abuse in Iran}

The unrealistic prices of electricity produced and the fuels consumed in power plants have an adverse effect on the social indicators that are analysed below. The energy intensity index (or TPES per GDP) is calculated by dividing the total primary energy consumption index by GDP, which is the inverse of energy efficiency. The carbon intensity index is also calculated by dividing $\mathrm{CO}_{2}$ emissions by total primary energy consumption.

According to Fig. 13, the carbon intensity index over the 50 -year period has been relatively low fluctuating. Carbon intensity has changed from 95 (in 1971) to 88 (in 2017), Iran's GDP per population has been on a steady upward trend since 1981, and energy intensity has also increased substantially.

According to Fig. 14, the energy intensity index for Germany, USA and France, as well as for the world average, has been declining, which means a tangible increase in energy efficiency in the world and advanced economies. At the same time, the energy intensity for the Iranian economy over the past 50 years has been quite reversed with global developments and unfortunately has always increased.

According to Fig. 15, the carbon intensity index for electricity consumption, despite relative fluctuations, has changed from 72.1 (in 2005) to 71.7 (in 2017), which is insignificant.

According to Fig. 16, the energy intensity index for electricity consumption, similar to the energy intensity index, has an upward trend, which means the continued decline in electrical energy efficiency in Iran. (While reducing overall energy efficiency) This indicates the need for urgent fundamental reform.

\section{ANALYZING THE SUCCESSFUL EXPERIENCES OF ELECTRICITY PRICE REFORM IN THE WORLD}

The strategic role of energy carriers in economic and

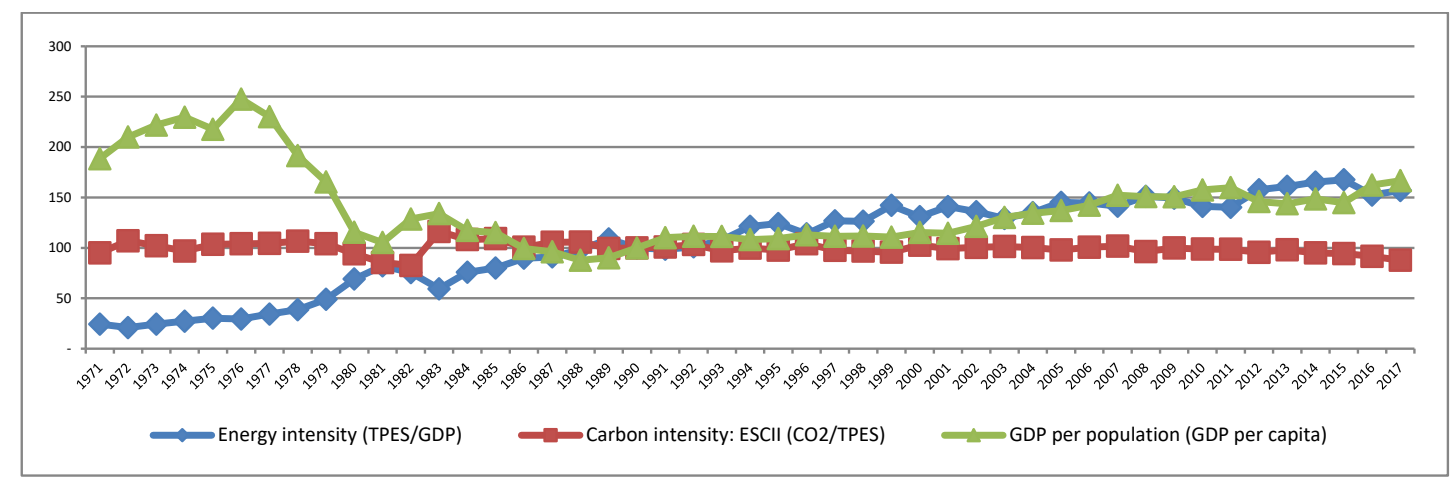

Reference: IEA. 2019a. $\mathrm{CO}_{2}$ Emissions from Fuel Combustion Highlights.

Fig. 13: Comparison of energy intensity, carbon intensity and GDP per population indexes of Iran in 2017.

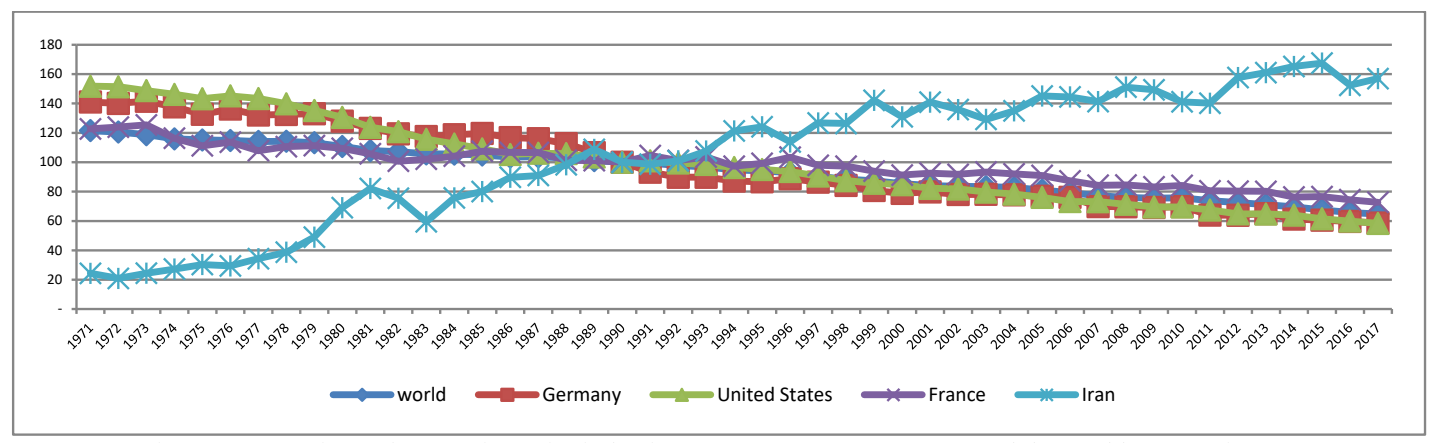

Reference: IEA. 2019a. $\mathrm{CO}_{2}$ Emissions from Fuel Combustion Highlights.

Fig. 14: Comparison of energy intensity index in Iran, Germany, US, France and the world average in 2017. 


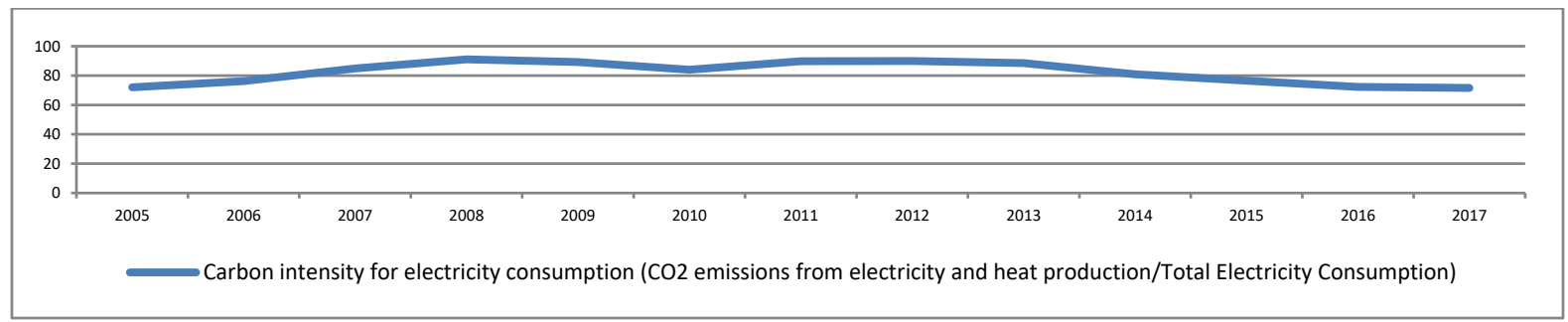

Reference: Ministry of Power. 2019. Energy Balance Sheet - 2017.

Fig. 15: Carbon intensity index trend for electricity consumption in Iran (power plant section).

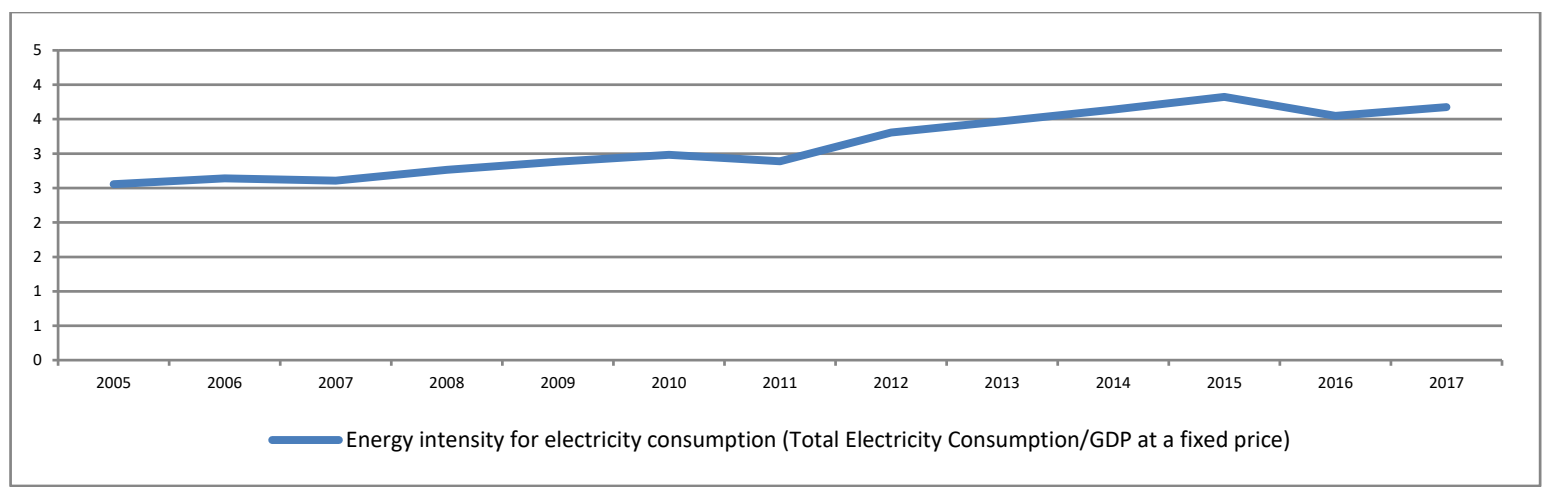

Reference: Ministry of Power. 2019. Energy Balance Sheet - 2017.

Fig. 16: Energy intensity index trend for electricity consumption in Iran (power plant section).

social development has made the energy sector one of the main focal points for subsidies. However, contrary to the original objectives, the granting of subsidies has imposed enormous social, economic and environmental costs on communities, some of which have only been mentioned. Under the 2015 Paris Global Agreement, governments, using funds derived from the reduction of energy subsidies, must lay the groundwork for massive investment in renewable energy and also reduce fossil fuel consumption by setting targeted guidelines and laws (Merrill et al. 2017). A review of the global experience of reforming energy subsidies in 28 countries suggests that obstacles to reform, such as lack of sufficient information on the actual volume of subsidies, lack of government credibility, concerns about the adverse effects of subsidies removal on poor households, contradictions with the interests of groups benefiting from the current situation, as well as the reverse effects of removing subsidies on inflation, international competition and domestic energy price fluctuations and so on, make the implementation of the reform program costly and challenging in many countries (Amirkhanlo 2018). The results of electricity subsidy reform in different countries are summarized in Table 5.

According to reports from the IMF (2013), Coady et al. (2016), Krane (2018) and the IEA (2019b), the strategy of adjusting subsidies for the electricity industry may vary depending on the circumstances of each country, but there are four key components to the success of electricity industry reform as a result of the above mentioned studies:

\section{Design a Comprehensive Strategy for Reform}

Successful reform always has a clear, long-term reform strategy that leads to increased efficiency in energy consumption and supply. There is a strong inverse relationship between the volume of subsidies and the quality of services, reflecting the diminishing effect of subsidies on investment in the sector. People are often reluctant to pay higher prices until the quality improves. Reforms in this sector should not only seek to increase access and quality of services but should also eliminate operational inefficiencies (such as high distribution losses and improper collection of bills). Having a comprehensive and long-term plan is the main reason for the success of reducing electricity subsidies in Armenia, Brazil and Kenya.

\section{Keep up with the Gradual Increase in Prices}

In the IMF's comparative studies, the average time required for a reform to succeed is 5 years on average, and generally, the gradual increase in prices depends on the political and 
Table 5: Summary and results of reforming electricity subsidies in different countries in the world.

\begin{tabular}{|c|c|c|c|c|c|}
\hline Country & Reform episode & $\begin{array}{l}\text { Reform out- } \\
\text { come }\end{array}$ & Reform impact & $\begin{array}{l}\text { IMF-Supported } \\
\text { Program during the } \\
\text { reform episode }\end{array}$ & $\begin{array}{l}\text { Conditionality } \\
\text { on energy } \\
\text { subsidy reform }\end{array}$ \\
\hline Armenia & Mid-1990s & Successful & $\begin{array}{l}\text { The electricity sector financial deficit declined from } \\
22 \text { percent of GDP in } 1994 \text { to zero after } 2004\end{array}$ & Yes & Yes \\
\hline Turkey & $1980 \mathrm{~s}$ & Successful & Generated additional revenues for maintenance & Yes & Yes \\
\hline $\begin{array}{l}\text { Philip- } \\
\text { pines }\end{array}$ & 2001 & Successful & $\begin{array}{l}\text { Subsidies declined from } 1.5 \text { percent of GDP in } \\
2004 \text { to zero in } 2006\end{array}$ & No & - \\
\hline Brazil & $1993-2003$ & Successful & 0.7 percent of GDP & Yes & Yes \\
\hline Mexico & $1999 / 2001 / 2002$ & Unsuccessful & not applicable & Yes & No \\
\hline Kenya & Mid-1990s & Successful & $\begin{array}{l}\text { Subsidies declined from } 1.5 \text { percent of GDP in } \\
2001 \text { to zero in } 2008\end{array}$ & Yes & Yes \\
\hline Uganda & 1999 & Successful & 2.1 percent of GDP & Yes & Yes \\
\hline
\end{tabular}

Reference: IMF. 2013. Case studies on energy subsidy reform: lessons and implications.

social conditions, the financial position, the social security and insurance system, and so on. According to the experiences of Mauritania 2008 and Nigeria 2012, the sharp rise in prices can be a serious obstacle to reform. In 7 of the 28 cases under study (such as Brazil and Peru), they used the price step-up approach in the electricity industry and initially for high-end subscribers in residential, commercial and public services.

\section{Adopt Political Measures in Line with Reforms}

Targeted measures to mitigate the effect of rising prices on the poor to win public support are crucial in reforming subsidies. Cash payments to offset the costs of subsidy reform can be limited to the consumption of the poorest sections of society and conserve government funds because poor families typically consume less energy than rich families. In Armenia, Brazil, Kenya and Uganda, electricity tariffs were kept constant to the minimum level of consumption, but for high consumption levels, tariffs increased. In the Philippines, very poor families were also subsidized for electricity consumption.

\section{Remove Policy from Price Mechanism}

Automated mechanisms are generally used to eliminate non-market energy pricing and reduce the adverse effects of reform. In South Africa, the Philippines and Turkey, the most detailed information about this mechanism and its implementation, through government and media policies, has been reported. However, in some cases, the adoption of such mechanisms has failed due to the significant transfer of international prices to consumers.

In order to prevent a sharp rise in domestic prices, the main point in the failure of reforms sustainability, a price- adjusting rule with an automated pricing mechanism can be used. Adjustment mechanisms, if backed by appropriate macroeconomic policies, can stave off inflationary expectations and gradually offset the effects of sharp increases in international prices and exchange rates to domestic prices to drastically reduce the likelihood of prices returning to the pre-reform period.

\section{DISCUSSION AND CONCLUSION}

Current patterns of energy production and use, while contributing to economic growth, are also a threat to environmental sustainability, health, and well-being of present and future generations. Therefore, paying attention to environmental impacts in economic activities is an important necessity (Sajadifar et al. 2016). In the not too distant future, the world will face two major crises of environmental pollution from fossil fuel combustion and increasing acceleration to complete these resources. Two strategies: diversifying the energy supply system and energy consumption management, are the main solutions (Barimani et al. 2018).

\section{Necessity of Reforming Electricity Generation Pattern Through Revision of Production Process and Reduction of Fossil Fuel Consumption}

The results of this study indicate that due to the low volatility of carbon intensity index during 47 years and carbon intensity index for electricity consumption during 13 years, no significant changes in the energy production process and especially electricity in Iran have been done. Due to the massive consumption of fossil fuels in power plants, the externality costs of power generation has increased significantly. The use of strategies adopted in developed countries, to account for the externality costs on the price of 
electricity, will certainly justify the production of electricity from renewable sources in Iran. On the other hand, the long construction time of electricity projects and their dependence on the economy has necessitated planning for the future of the electricity grid in order to meet timely and economical electricity demand. Under Article 50 of the Sixth Economic Development Plan of Iran, the government is required to raise the share of renewable and clean power plants, with the priority of investing in the non-governmental sector and with maximum internal capacity utilization, to at least $5 \%$ of the country's electricity capacity by the end of the program. But there are actually numerous problems in operating it. Analysis of Iran's electricity industry data shows that electricity generation from renewable sources (wind, solar, biogas and thermal recycling) in Iran has always been negligible (and increased to $476.9 \mathrm{MW}$ in 2017 , which is only $0.6 \%$ of the country's total power capacity), and even after privatization and a number of reforms, the index of fundamental reforms in electricity production in 2017 has grown to only $7.6 \%$, which can be worrying. However, in highly successful countries such as Iceland, Switzerland, Norway, Sweden and Luxembourg, over $90 \%$ of electricity production comes from sources other than fossil fuels. Hydropower plants in these countries have the highest electricity production and, after hydropower, each of these countries has invested heavily in one or some renewable resources to suit their needs. Hydropower plants (due to power generation through dam construction, flood control, agricultural and potable water supply, reduced fuel consumption, environmental pollution, ease of use, poor domestic consumption, quick stop and start, grid frequency control, poor maintenance cost and easier power plant construction) are the most favoured and, for these reasons, the dominant part of successful countries. Iran's hydropower capacity has increased by $372 \mathrm{MW}$ in 2017, and it is planned to increase $1313 \mathrm{MW}$ to hydropower plants by 2022 . However, the share of hydropower plants in electricity production has actually been declining for the last three decades. Comparison of the index of fundamental reforms in electricity production with 30 sample countries as well as the results of Razini et al. (2011), Sajadifar et al. (2016) and Kachoi \& Amidpour (2016) studies, the necessity of revising the process of electricity generation and reduction of fossil fuel consumption can be confirmed and emphasized. The use of alternative (renewable) energy sources, while reducing dependence on an energy carrier and diversifying the energy supply system, has both the advantages of energy saving and the reduction of energy pollution.

\section{Necessity of Reforming the Pattern of Electricity Consumption Through Price Management and Targeted Reduction of Subsidies}

Electricity has been one of the strategic inputs of production in any country whose long-term growth depends on the ability of power plants to supply electricity efficiently. Paying large direct and indirect subsidies to Iran's power industry, while reducing tangible efficiency, makes fuel power plants enter the process of production at an unrealistic and lower price as well as makes electricity available to the end consumer at a lower price than the actual level. As such, large industries and power producers have no economic incentive to invest and plan to save on fossil fuel or electricity as feed. The only significant and applicable government policy is the extensive effort to replace Natural Gas with other fossil fuels as shown in Fig. 7. Finally, the end user of electricity in all sectors, given the fact that it receives electricity far below its actual cost, has no incentive to invest and use modern technology to reduce electricity consumption. According to Kiani et al. (2017), the main problem of the government, in general, is the unwillingness of the people to pay the extra costs due to the replacement of renewable energies with other energies and even the lack of optimal participation in the implementation of government programs in this regard. Paying for subsidies makes it even worse that, unfortunately, in 2018, Iran has paid the most subsidies in the world.

The study of the energy intensity and energy intensity for electricity consumption and their undesirable trend in Iran can indicate worrisome in the area of socio-economic effects of abuse and increase inefficiency for both energy and electricity. The energy intensity in Iran, with a continuous upward trend, has risen from about 24 (in 1971) to a very alarming 157 (in 2017). However, the steady decline in this index over the same period for average world economy and developed countries indicates the degree of deterioration and the need for quick corrective action. According to Asadi et al. (2016), lower fuel prices of power plants and lower electricity prices have led to uneconomic and relatively higher electricity consumption, which means the need for higher electricity generation and imposing heavy subsidy costs on the government. And given that the electricity generation process is also based on the wider use of fossil fuels, more use of fossil fuels means imposing a second subsidy pressure on the state (imposing more subsidies on gas and oil sectors as indirect subsidies for the electricity industry) and creating wider pollution due to the greater use of fossil fuels. Therefore, this is contrary to the goals of sustainable development. This issue, along with Iran's unfavourable global rank in providing large subsidies, the increasing trend of energy intensity and $\mathrm{CO}_{2}$ emissions in Iran and the results of studies by Majdzadeh Tabatabaei et al. (2016) and Gholipour Khatir et al. (2018), emphasizes the need to accelerate the implementation of reforms in the subsidies and the pattern of energy consumption (particularly electricity). 
Implementation of electricity consumption management, by promoting energy efficiency, guarantees optimum and economical utilization of it and will lead to the reduction of energy pollution in Iran.

\section{POLICY SUGGESTIONS}

The need to create efficiency and increase productivity in the energy consumption pattern and its production process concurrently is of particular importance in order to achieve sustainable development, and the following suggestions should be taken seriously:

1. Reducing subsidies in the electricity sector alone cannot be effective, because power plants get fuel from both gas and oil derivatives sectors, which have much more subsidies. Therefore, the reduction of subsidies in the form of a comprehensive plan will be formulated in all three sections and special attention will be paid to the links between these three sections. The government's policy of late 2019 to begin lowering the subsidy on Gasoline alone may not be optimal, as reforming the price of one energy carrier will cause double disruption of market mechanism and investment to replace other (relatively cheap) energy carriers.

2. Heavy investment in sustainable development by the government is crucial. Worryingly, the inefficient use of the revenue generated by the reduction of subsidies and the use of this revenue to cover current expenditures and the government's budget deficit cannot be effective at all. For example, the production of hybrid cars alone cannot mean less Gasoline and Diesel Fuel consumption, but also according to Merrill et al. (2017), heavy infrastructure investment such as the creation of a major hybrid vehicle manufacturing structure, the creation of car charging stations, the transfer of transportation system from fossil fuel consumption to electricity, and several important incentive investments and policies should be made by the government.

3. Due to the heavy cost of building renewable power plants and the study of Kiani et al. (2017) on the necessity of government action in this regard, while reducing subsidies, resources should be utilized to improve the electricity generation process. In the absence of this improvement, all policies in the area of sustainable development can lead to failure. In the example above: by investing heavily in hybrid cars and transferring their fuel from fossil fuels to electricity, the direct consumption of fossil fuels in cars and transportation system will decrease and electricity consumption will increase sharply. However, if the electricity generation process continues to be associated with greater use of fossil fuels, there will again be an increase in the use of fossil fuels to generate more electricity. This phenomenon means getting caught in a vicious cycle.

4. The second strategic solution for the heavy cost of transferring the electricity generation process from fossil fuels to renewables is to exploit the potential in hydropower. Unfortunately, unlike the successful experiences in developed countries, the share of hydropower plants in electricity production in Iran has been declining, which can be clearly deduced by comparing the index of fundamental reforms in electricity production with the 30 countries in Table 2. Accordingly, the government should formulate an efficient plan to increase the tangible utilization of hydropower plants and build new ones.

5. Given the unsuccessful implementation of the subsidy reform plan in Iran in the last decade and the recent government planning to re-enforce it, it is crucial to take advantage of successful countries' experience in reforming the electricity industry and paying attention to the four key components mentioned. Cross-sectional increasing energy prices (motivated by price gaps between home and abroad) may not be an efficient activity, because, according to some countries' experiences, after a while and for various reasons, subsidies generally return to pre-reform conditions. Therefore the implementation of the price-adjusting rule, along with the automated pricing mechanism and the specific role of the government in the remote control of this mechanism, is of particular importance in ensuring the success of energy price reform. This should definitely be used in Iran.

\section{REFERENCES}

Amirkhanlo, M. 2018. Review of current issues of Iranian economy. Center for Research and Economic Studies. Economic deputy. Iran Chamber of Commerce. Industries and Mines and Agriculture (ICCIMA). Tehran, pp. 1-75.

Asadi, F., Karim, M.H. and Feshari, M. 2016. The competitiveness of Geothermal power compared to conventional methods of electricity generation in Iran. Journal of Iranian Energy Economics, 5(18): 1-27.

Barimani, M., Salnasaryan, A., Sadeghi, H. and Kaabi-Nejadian, A. 2018. Modeling of prioritization of policies in the development of the power generation industry of Iran using LEAP. Quarterly Energy Economics Review, 14(58): 139-168.

Bose, B.K. 2010. Global warming: energy, environmental pollution, and the impact of power electronics. Institute of Electrical and Electronics Engineers (IEEE), 4(1): 6-16.

Coady, D., Parry, I., Sears, L. and Shang, B. 2016. How large are global fossil fuel subsidies? World Development, 91: 11-27.

Foley, E., Blomberg, M. and Girard, L. 2014. 2013 wholesale electricity prices in New England rose on higher Natural Gas prices (pipeline constraints and higher demand pushed up prices for both natural gas and power). ISO New England (responsible for the reliable operation of New England's electric power generation...). Press Release, pages 1-3. 
Gholipour Khatir, F., Mazyaki, A. and Houri Jafari, H. 2018. Effect of cutting subsidies on technical efficiency of power plants in Iran. Quarterly Energy Economics Review, 14(57): 125-146.

Guler, T. and Gross, G. 2005. A framework for electricity market monitoring. 15th Power Systems Computation Conference (PSCC). Liege. Belgium, pp. 22-26.

IMF. 2013. Case studies on energy subsidy reform: lessons and implications. Prepared by: a staff team led by Clements, B., and comprising Coady, D., Fabrizio, S., Dizioli, A. and et al. International Monetary Fund: Washington, D.C. - Tax expenditure.

International Energy Agency. 2019a. $\mathrm{CO}_{2}$ Emissions from Fuel Combustion Highlights. Statistics and full analysis of emissions stemming from energy use. IEA Publications. 2019 Edition. France.

International Energy Agency. 2019b. Fossil-Fuel Subsidies Report. IEA fossil fuel subsidies database: contains fossil-fuel subsidies estimates by country from the IEA's World Energy Outlook 2019. For more information on this publication please visit: https://www.iea.org/weo.

Kachoi, M. and Amidpour, M. 2016. The scenario analysis on greenhouse gas emission mitigation potential in the Iranian electricity sector using LEAP model. Iranian Journal of Energy, 19(3): 101-115.

Kiani, S., Shahraki, J., Shahraki, A. and Akbari, A. 2017. Application of double-bounded dichotomous choice contingent valuation to study the possibility of using new energy in Iran's power generation. Journal of Iranian Energy Economics, 6(22): 133-163.

Kianvand, M. and Farzinvash, A. 2015. The effect of electricity forward contracts trading in the energy exchange on the volatility of spot prices in Iran electricity market. Journal of Iranian Energy Economics, 4(16): 181-207.

Krane, J. 2018. Political enablers of energy subsidy reform in Middle Eastern oil exporters. Nat. Energy, 3: 547-552.

Majdzadeh Tabatabaei, Sh., Hadian, E. and Zibaei, M. 2016. Determining proper subsidy to renewable energy in Iran: a Hybrid approach of CGE model. Journal of Iranian Energy Economics, 5(17): 129-167.

Merrill, L., Bridle, R., Klimscheffskij, M. et al. 2017. Making the switch: from fossil fuel subsidies to sustainable energy. Nordic Council of Ministers. Nordic co-operation, TemaNord 2017: 537, Rosendahls, Denmark, pp. 1-81.

Ministry of Power. 2019. Energy Balance Sheet-2017. (Amini, F., Shafizadeh, M. et al.). Office of Planning and Macroeconomics of Electricity and Energy. First Edition. Iran.

Ministry of Power. 2020. An Overview of Energy Statistics in Iran (30 year energy statistics). (Shafizadeh, M., Amini, F. et al.). Office of Planning and Macroeconomics of Electricity and Energy. First Edition. Iran.

Moshiri, S., Morovat, H. and Nasiri, A. 2018. The impact of liberalizing fuel prices on power plants' offered electricity prices using an agent based model. Quarterly Energy Economics Review, 14(56): 1-34.
Pourebadollahan, C. M., Fallahi, F., Heydari, K. and Kiani, P. 2019. Economic regulation design for the electricity distribution companies of Iran. Quarterly Energy Economics Review, 15(60): 191-225.

Razini, S., Moghadastafreshi, S.M. and Bothaei, S.M. 2011. Scenario planning with the aim of future study on Iran power generation industry. Iranian Journal of Energy, 13(35): 1-14.

Razmi, J., Ghaderi, S.F. and Zokaei Ashtiani, A. 2010. Analysis of competitive assessment indexes in electricity market of Iran. Journal of Business Management, University of Tehran, 2(2- Serial Number 5): 41-60

Sajadifar, S.H., Asali, M., Fathi, B. and Mohamadbagheri, A. 2016. Measuring energy consumption efficiency using Data Envelopment Analysis (DEA) with undesirable factors. The Journal of Planning and Budgeting, 20(4): 55-70.

Shahidepour, M., Yamin, H. and Lee, Z. (as authors). 2005. Market operations in electric power systems forecasting, schedduling, and risk management. Seifi, H., Yousefi, G. \& Pedram, M.H. (as translators). Power Networks Studies and Planning Center, Tarbiat Modarres University, Tehran, pp. 1-665.

Shih, Y., Shi, N., Tseng, C., Pan, S. and Chiang, P. 2016. Socioeconomic costs of replacing Nuclear power with fossil and renewable energy in Taiwan. Energy, 114: 369-381.

Stern, J. 2014. International gas pricing in Europe and Asia: a crisis of fundamentals. Energy Policy, 64(C): 43-48.

Tirole, J. 2014. Market power and regulation. The Economic Sciences Prize Committee of the Royal Swedish Academy of Sciences, scientific background on the Sveriges Riksbank Prize in Economic Sciences in Memory of Alfred Nobel, pp. 1-52.

Tladi, D. 2007. Sustainable development in international law: an analysis of key Enviro-Economic instruments. Environmental law. Pretoria University Law Press. Pretoria. South Africca, pp. 274.

Twomey, P., Green, R., Neuhoff, K. and Newbery, D. 2005. A review of the monitoring of market power: the possible roles of transmission system operators in monitoring for market power issues in congested transmission systems. Journal of Energy Literature, 11(2): 3-54.

United Nations. 2011. Sustainable development report on Africa I: managing land-based resources for sustainable development. Economic Commission for Africa, UNCSD.

U.S. Environmental Protection Agency. 2014. Catalogue of CHP technologies. Combined Heat and Power Partnership, page 1.

Wang, K. and Wei, Y. M. 2016. Sources of energy productivity change in China during 1997-2012: a decomposition analysis based on the Luenberger productivity indicator. Energy Economics, 54: 50-59.

Wheeler Stephen, M. 2013. Planning for sustainability: creating livable, equitable and ecological communities. Routledge. London and New York. UK \& USA, pp. 288. 